\title{
Relatedness Among Three Native Geese in Erbil Governorate Using Hematological and Molecular Methods
}

\author{
Mohsen A. Ahmed \\ Animal Resources Department \\ College of Agriculture \\ Salahaddin University \\ Erbil, Iraq \\ muhsin.ahmed@su.edu.krd
}

\author{
Yousif M.S. Al-Barzinji \\ Animal Resources Department \\ College of Agriculture \\ Salahaddin University \\ Erbil, Iraq \\ Yousif.Noori@su.edu.krd
}

\author{
Lanja Assad Ismail \\ Animal Resources Department \\ College of Agriculture \\ Salahaddin University \\ Erbil, Iraq \\ lanja.ismael@su.edu.krd
}

\begin{abstract}
The objective of present study was to determine genetic diversity among three geese color types using RAPD markers and hematological parameters. The overall mean, of the live weights, Hemoglobin, Hetrophil \%, Lymphocyte \%, Monocyte \% and $\mathrm{H} / \mathrm{L}$ ratio were $3.006(\mathrm{~kg}), 14.64,36.896,49.896$, 2.233 and 0.736 respectively. The breed, sex and interaction between them have significant effect on live body weight, Hemoglobin and Monocyte \%. Ten primers were used and six out of them were selected based on their number of bands (NB) and polymorphic characteristics. A total of 309 bands observed, ranged from 30 in primer OPB-07 to 54 bands in OPA-20. Five unique bands were found only in white goose, whereas the highest unique band was obtained in primer OPB01 locus. Overall genetic distance among native geese arrived 64.122 and phylogenetic dendrograms showed that 3 clusters, the first cluster content only white geese (Male and Female) breed, the second one cluster is included piebald geese breed (Male and female) and third one was including gray geese (Male and female) breed. It was concluded that the white geese was closer to piebald geese than to the gray geese breed. The high genetic distance $(64.122 \%)$ and variation in phenotypic value such as live weight (2.375 to $3.600 \mathrm{~kg} / \mathrm{bird}$ ) for three native geese indicates that these native geese have a good amount of genetic resources to made genetically improvement in further and it means the three goose samples are independent breeds.
\end{abstract}

Keywords: Geese, Hematology, RAPD-PCR, Genetic Distance.

\section{INTRODUCTION}

Geese bird is important poultry commodity for Asian villagers. In Asian the aims of breeding geese country is not only to meat or eggs but also to use them as guard birds and to help control and limited the growth of non wonted grass and weeds. The genetic capacity of Asian geese (Egg or meat production) is generally accepted as less when compared with that in Europe which has modern geese breeds [1]. Even the goose production technology in Asian is not well developed; in Asia goose production is increasingly popular and has become accepted as the type of water bird production [1].
The increased for meat production from geese breeding return to as it is very appropriate for organic bird production and supporting to rural developments [2-5].Live body weight was different among geese breeds were ranged from 3 to $7 \mathrm{~kg}$ [6-9].

Assessing genetic variability within or among breeds is essential for genetic diversity among the animal populations. The complete population structure helps to plan strategies for conservation and development of a breed [10]. Genetic variation is the raw material for the breeders, who utilize domestic animal species to people's needs. Furthermore, the increasing genetic data on geese bird using different genetic markers will help to understand the evolutionary history of geese. In addition, it will help to refine the definition of breed [11 and 12]. Recently, molecular markers, revealing polymorphism at the molecular level, has play an essential goals in poultry breeding studies. The random amplification polymorphism DNA (RAPD) marker has been widely used, due to its easy utilization by simple PCR, followed by a denaturing gel electrophoresis for number of fragments and fragments size determination [13].

RAPD markers are adopted as a powerful molecular finger-printing technique which allows distinction even between closely related genotypes. The aim of study is to identify the genetic polymorphism for native geese in Iraq using PCR-RAPD technique.

\section{METHODS AND MATERIALS}

2.1 Geese samples, DNA extraction and hematological tests:

This study was conducted on three local geese breeds (Fig. 1) Whitse breed, piebald breed and gray breed (15 males and 15 females for each color). A total of 90 geese (12 \pm 1 month) blood samples ( $3 \mathrm{ml} / \mathrm{bird}$ ) were collected (Figure 1) from jugular vein into $5 \mathrm{ml}$ vacutainer tubes containing the EDTA for DNA extractions (DNA was extraction from the blood sample using QIAamp ${ }^{\circledR}$ DNA Blood Mini Kit ,QIAGEN GmbH Qiagenstr.1 40724 Hilden Germany) and for hematological parameters (Haemoglobin concentration (HB), Packed cell volume (PCV), Erythrocyte Sedimentation Rate (ESR) and Differential Leucocyte Count estimated according to [14-17] , respectively. All laboratory work was done in the biotechnology laboratory at the Department of Animal Resources, College of Agriculture, and 
Salahaddin University-Erbil. The quantity and quality of DNA were determined by Nanodrop spectrophotometer and $1 \%$ agarose gel electrophoresis, respectively but for PCR products we used $1.5 \%$ agarose gel to determent the RAPD bands.

\subsection{RAPD primers}

In the present study, a total of ten RAPD primers (Table, 1) which were obtained from CinnaGen Inc.; (Iran) were used. Six of them amplified and gives clear band.

\subsection{PCR amplification of RAPD primers}

Amplifications were performed using a thermal cycler (MJ RESEARCH-PTC-200 Gradient Peltier Thermal Cycler ${ }^{\circledR}$ 60- Well) with the final reaction volume of 20 $\mu \mathrm{L}$. Two $\mu \mathrm{L}$ sample DNA was added to each tube to make the final volume $(20 \mu \mathrm{L})$. Each reaction contained: $11 \mu \mathrm{L}$ of Red Master Mix (AMPLIQON A/S Stenhuggervej 22-Germany), 25 Units/mL Taq polymerase, each dNTPs is $200 \mu \mathrm{M}$ and $\mathrm{MgCl} 2$ was 1.5 $\mathrm{mM}), 2 \mu \mathrm{L}$ of RAPD primer $(197.13 \mu \mathrm{M}-599.26 \mu \mathrm{M}), 2$ $\mu \mathrm{L}(30 \mathrm{ng})$ of DNA template and $5 \mu \mathrm{L}$ of DNase free water. Many protocols were used but only one protocol gives as clearly bands. The primers (OPA-04, OPA-14, OPA-20, OPB-01, OPB-07 and OPB-12): programmed for 35 cycles of denaturation at $95{ }^{\circ} \mathrm{C}$ for $1 \mathrm{~min}$, annealing at $37-40{ }^{\circ} \mathrm{C}$ for $1 \mathrm{~min}$ and extension at $72{ }^{\circ} \mathrm{C}$ for $1.5 \mathrm{~min}$. An initial denaturation step of $5 \mathrm{~min}$ at 95 ${ }^{\circ} \mathrm{C}$ and a final extension step of $7 \mathrm{~min}$ at $72{ }^{\circ} \mathrm{C}$ were included in the first and last cycles, respectively. The PCR amplification products were run in a $1.5 \%$ agarose gel (Staining with Ethidium bromide in Tris-borate EDTA buffer) and visualized under UV transillumination. The control reactions were set up without genomic DNA to avoid any DNA contamination.

\subsection{Genotypic and statistic analysis}

The RAPD bands were scored as present (1) or absent (0) in each pattern. All genetic parameters in present study were calculated by using Genepop software, version, 3.3 [18].

The PROC GLM (General Linear Model) procedure [19] was used to analyze the data and Employed for evaluation of live weight and blood traits. Strain, sex and interaction between them were fitted in the following model:

$Y i j k=\mu+A i+B j+(A B) i j+\varepsilon i j k i=1, \ldots, 3 ; j=1, \ldots, 2 ; k$ $=1, \ldots, 6$

Where:

Yijk = observation $\mathrm{k}$ in level i of factor A (Breed) and level j of factor B (Sex)

$\mu=$ the overall mean

$\mathrm{Ai}=$ the effect of level $\mathrm{i}$ of factor A (1= Gray, 2= White and $3=$ Piebald)

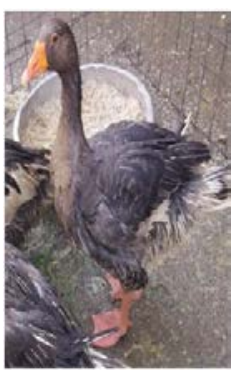

Gray

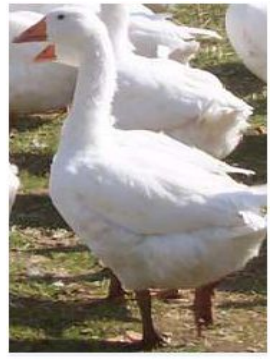

White

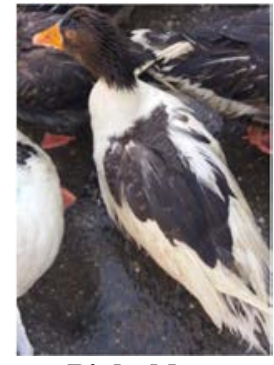

Piebald
Figure 1. Image of geese breeds.

\section{RESULTS}

\subsection{Phenotypic results}

This part of results included the performance traits under studies:

\subsubsection{Body weight and blood traits}

The overall mean, of the live weights and blood traits were presented in Table (2). Mean live weight was 3.006 (kg). The live weight in this study was higher than reported by [20] in same breeds was arriver $(2.933 \mathrm{Kg})$. In the other side's this results was lower than reported on different geese breeds at the same age [6] 5.534, [7] 6.730 , [8] 3.972, [21] 3.657, and [9] $3.470 \mathrm{~kg}$.

The higher lives weight $(\mathrm{P} \leq 0.001)$, were recorded in Piebald (3.225 kg) and White (3.158 kg) geese while lower was observed in Gray $(2.637 \mathrm{Kg}$ ) geese (Table, 2).

Table 1: Name, sequence and percentage content of GC for all used primers

\begin{tabular}{cccc}
\hline No. & $\begin{array}{l}\text { Primer } \\
\text { name }\end{array}$ & Primer sequence 5'to 3' & GC \% \\
\hline $\mathbf{1}$ & OPA-04 & AATCGGGCTG & 60 \\
$\mathbf{2}$ & OPA-14 & TCTGTGCTGG & 60 \\
$\mathbf{3}$ & OPA-20 & GTTGCGATCC & 60 \\
$\mathbf{4}$ & OPB-01 & GTTTCGCTCC & 60 \\
$\mathbf{5}$ & OPB-07 & GGTGACGCAG & 70 \\
$\mathbf{6}$ & OPB-12 & CCTTGACGCA & 60 \\
\hline
\end{tabular}

The sex had significant effect on the live weight (Table, $3)$. Male's geese at 1 year of age produced significantly $(\mathrm{P} \leq 0.01)$ heavier live weight than female at same age, this result may be due to the male's hormone effect, which testes male product testosterone hormone which have positive role to increasing the body weight. Similar result reported by [20] for significantly of sex in body weight. A table (4) presents the interaction of breed with whereas sexes. Significance interaction were found between breeds and sexes in weight higher value 3.60 recorded in male Piebald and lowest value $(2.375 \mathrm{~kg})$ in female gray geese. These results show good variation in live weight for native geese due to phenotypic and genotypic variation between native geese and selection for above traits within native geese can speed up the performance in native geese in Kurdistan.

Table (2) shows the differences among native geese in blood traits. The overall means of Hemoglobin, Hetrophil \%, Lymphocyte \%, Monocyte \% and H/L ratio were 14.64, 36.896, 49.896, 2.233 and 0.736 respectively. The results show significant differences among strains in Hemoglobin and Monocyte\% (Table 2). Non significant results obtained in this study for sex 
(Table, 3) on blood traits except in Monocyte \% the female's geese have higher value than males. As in table (4) the significance interaction between breeds and geese sexes were found in Hemoglobin and Monocyte \% were higher hemoglobin value $\left(17.65 \mathrm{~g} / 100 \mathrm{~cm}^{3}\right)$ recorded in White male goose.

\subsection{Genotypic results}

This part of results included the RAPD-PCR amplification and molecular analysis for six RAPD primers in all geese samples under study:

\subsubsection{Number (NB) and size of bands (bp)}

The total of six primers amplified showed clear bands and were to investigate the genetic variations among the three local geese breeds. All of the six primers were polymorphic over all geese samples (Figures 2). The overall NB for the 6 primes was 309 bands, ranged from 30 in primer OPB-07 to 54 bands in OPA-20 (Table 5). The highest NB found in white Male (57 fragments) and the lowest (46 fragments) was detected in Gray female (Table 5). Results in this study were higher than reported by [22], (2005) were found 102 bands from seven RAPD primers.

As in Table (5) the bands size range over all the native geese, started from $100 \mathrm{bp}$ and ended at $2000 \mathrm{bp}$. The smallest size of bands was recorded for OPA-04, OPA14 and OPA-20 (100 bp) in white, piebald and gray , while the highest size bands range was recorded for primer OPB-01 locus (2000 bp ) in all males and females native geese . Similar results was reported by [22], (2005) in Polish goose were size range of band ranged from 200 t0 $1500 \mathrm{bp}$.

\subsubsection{Number of polymorphic bands (NPB)}

The overall \% polymorphism band for 309 bands in present study was 14.868 and 17 of 309 bands is polymorphic bands; among the primers the OPA-04 have higher band with higher polymorphic bands was arrived 42.86\% (Table 6). Depended on above results, there are possibility to recommended that these loci can be use to define genetic distances among the present native geese. The results were agreed with than reported by [23] in Magpie geese and [22] in Polish goose.

\subsubsection{Unique band}

Out of six primers one of them gives unique band, the highest numbers was obtained by primer OPB-01 locus, which had 5 bands, all of them were unique (ranged from 250 to $1500 \mathrm{bp}$ ) and found in white goose.

\subsubsection{Nei's gene diversity and Shannon's information index (I)}

The gene diversity/heterozygosity and Shannon's information index in averaged 0.4815 and 0.6743 , respectively. These results indicate the diversity among geese's breed are moderately high.

\subsubsection{Phylogenetic tree}

As in the dendrograms (Figure, 3), the overall genetic distance among native geese arrived 64.122\% and three clusters were found, the 1 st cluster branch consisted of the white geese (Male and female) breed, the second one cluster is included piebald geese breed (Male and female) and third one was including Gray geese (Male and female) breed.

These results indicated that the gray geese breed is most genetically distant from the white and piebald geese breeds (64.122\%), while this cluster indicates a close relationship recorded between Piebald and White was arrived and the results indicated that the Piebald breed was closer to White breed (43.266\%) than to the Gray geese breed. Similar results were reported by [23] in Magpie geese and [22] in three line of Polish goose were genetic distance ranged from $23 \%$ to $89 \%$.

\subsection{Phenotypic and genotypic traits}

According to the hematological results in Table (2) and genotypic results in Figure (3) the gray geese's was different from both white and piebald goose, while the last two one is nearly to each other, it means the hematological differences return to the differences in genetic factors and can used it for characterization of bird breeds. On the other side there are high significant differences ( $\mathrm{p} \leq 0.001)$ between white and piebald with gray geese breed for live body weight, also there are higher genetic distance between white and piebald with gray geese was arrived $64.122 \%$.Theses results give us clear idea show that the phenotypic values such as weight and hematological parameters are under genotypic effect and recording of phenotypic values are necessary to obtained better image for diversity study in poultry breeding.

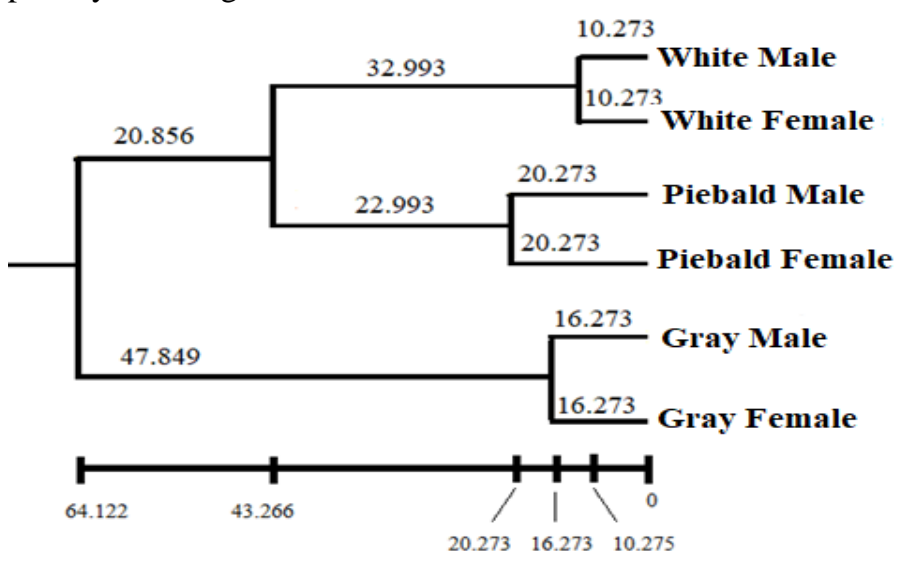

Figure 3. UPGMA dendrograms showing differentiation among geese breeds

Table 6: Total band and percentage polymorphic band.

\begin{tabular}{ccccc}
\hline No. & $\begin{array}{c}\text { Primer } \\
\text { name }\end{array}$ & $\begin{array}{c}\text { Total } \\
\text { Bands }\end{array}$ & $\begin{array}{c}\text { No. of Polymorphic } \\
\text { bands }\end{array}$ & $\begin{array}{c}\text { Polymorphic } \\
\text { bands (\%) }\end{array}$ \\
\hline 1 & OPA-04 & 21 & 9 & $42.86 \%$ \\
2 & OPA-14 & 19 & 4 & $21 \%$ \\
3 & OPA-20 & 22 & 1 & $4.5 \%$ \\
4 & OPB-01 & 20 & 0 & $0.00 \%$ \\
5 & OPB-07 & 12 & 1 & $8.33 \%$ \\
6 & OPB-12 & 16 & 2 & $12.5 \%$ \\
& Mean & & 4.1 & $14.868 \%$ \\
\hline
\end{tabular}




\section{CONCLUSION}

The high genetic distance (64.122\%) and variation in phenotypic value such as live weight (2.375 to 3.600 $\mathrm{kg} / \mathrm{bird}$ ) for three native geese indicates that these local geese have a good amount of variation to make genetically improvement in further and it means the three goose samples are independent breeds. The above results can be use by breeders to clarify the mapping of the genetic diversity of the local Iraqi geese and can depend on these results to make mating system or crossing among these native geese or selection within / among native geese to speed up the performance in native geese in Kurdistan. On other side there are similar results in both genetic and phenotypic results it is mean the recording for performance traits are necessary in poultry breeding for got clear image for diversity study in this field of science.

\section{ACKNOWLEDGEMENT}

The authors thank all persons who helped and supports during performing and done this research paper on native geese's in Iraqi-KRG.

\section{REFERENCE}

[1] T, Yuwanta, "Goose Production in Indonesi and Asia” Gadjah Mada University, Yogyakarta, 55281, Indonesia, 1999.

[2] N.A. Cave, , A.A. GrunderButler, A. Fortin and B.Pawluczuk, "Influence of age, sex and pre-slaughter holding conditions on live weight and carcass traits of broiler" Arch. Geflugelk., 58:106-110,1994.

[3] S.Çelebi , “Erzurum'da yetiştirilen kazların bazı önemli kesim ve karkas özellikleri üzerine bir araştırma” Uluslararası Hayvanc1lık'99 kongresi, İzmir,1999.

[4] T. Kırmızıbayrak, "Kars ilinde halk elinde yetiştirilen yerli ırk kazların kesim ve karkas ö zellikleri” Türk J. Vet. Anim. Sci., 26:667-670, 2002.

[5] R. Bochno, D. Murawska, and U. Brzostowska, “ Age-related changes in the distribution of lean fat with skin and bones in goose carcasses” Poultry Science, 85:1987-1991,2006.

[6] C. Larzul, R. Rouvier, R. Daniel and G. Guy, “ Estimation of genetic parameters for growth, carcass and overfeeding traits in a white geese strain” Genetic Sel, Evol., 32: 415-427, 2000.

[7] K. Dublecz, L. Pal, L. Wagner, A. Banyai, A. Bartos and SZ. Toth, " Modification of the n-3 fatty acid profile of meat -and livertype geese tissues" 16th European Symposium on Poultry Nutrition. 677-680, 2008.

[8] T. Sahin, M. Tilka, I. Kaya, Y.Unal and D. Elmali, “ Effect of different protein level for finishing period on fattening performance and carcass traits in native Turkish geese” Journal of Animal and Veterinary Advances, 7(11):1364-1369, 2008.

[9] B.Celik and Z.Bozkurt, “ Slaughter and carcass traits of native geese reared in Mus province” Lucrări ştiinţifice Zootehnie şi Biotehnologii, vol. 42 (2): 423-428, 2009.

[10] M. Steele, “ The Tropical Agriculturalist: Goats. Macmillan” Education Ltd. London and Basingstoke. UK, 1996.

[11] C.R. Henderson, “ Application of Linear Models in Animal Breeding” University of Guleph Publications, Guelph, Canada, 1984.

[12] H.J. Bearden and J.W. Fuquay, “Applied Animal Reproduction” Prentice Hall Inc. Upper Saddle River. New Jersey, 2000.

[13] E.V. Marle-Koster and L.H. Nel, “ Genetic markers and their application in livestock breeding in South Africa” South Afri-can J. Anim. Sci. 33, 1-10, 2003.

[14] H.Varley , A. H. Gownlock and M. Bell, "Practicale Clinical Biochemistry” 5th ed. William Heinemann, 1980.

[15] R.K. Archer, “ Haematological Techniques for Use on Animals” Oxford Black Scientific Publication, 1965.

[16] K.H. Saeed, and O.A.M. Al-Habbib, "Practical Animal Physiology" Dar-Al- Hikma and Publishing Company. Ltd. Mousul, 1990.
[17] A. Mualla, N.I. Abdulwahid, and Y. Yousif, "Practical Clinical Physiology ”1st ed . Dar-Al-Hikma publishing company . LtdMousul, 1990.

[18] M. Raymond and F. Rousset, "GENEPOP (version 3.3): Population genetics software for exact tests and ecumenicism” J. Heredity. 86, 248-249, 1995.

[19] SAS, “ Version 9 for Windows, Cary North Carolina USA: 19 institute Inc.,2004.

[20] L. A. Ismael, “ Hematological and productive Performance of male and female of three native geese in Kurdistan region of Iraq” Al-Anbar J. of Agr. Sci., Vol.: 9 No. (2):1-12, 2011

[21] E. Sahin, and M. Yardimci, "Effects of kefir as a probiotic on growth performance and carcass characteristics in geese ( Anser ancer) " Journal of Animal and Veterinary Advances, 8(3): 562567,2009.

[22] A.Q. Maciuszonek, G. Bartosz and B. Marek, “ RAPD-PCR Analysis of Various Goose Populations” Folia biologica (krakow), Vol 53:(1-2):83-85, 2005.

[23] L. Peggy, R. Antoni, and J. Peter, "Molecular genetics (RAPD) analysis of breeding Magpie geese” The Auk 113(3): 552-557, 1996. 
Table 2: Mean \pm SD for effect of geese breeds on weight and blood traits.

\begin{tabular}{|c|c|c|c|c|c|c|}
\hline Strain & Live weight (kg) & Hemoglobin g/ $100 \mathrm{~cm}^{3}$ & Hetrophil \% & Lymphocyte \% & Monocyte \% & $\mathrm{H} / \mathrm{L}$ ratio \\
\hline White & $3.158 \pm 0.35 a$ & $15.97 \pm 2.98 \mathrm{a}^{*}$ & $35.17 \pm 8.09 \mathrm{a}$ & $48.17 \pm 8.09 a$ & $2.14 \pm 0.48 b$ & $0.74 \pm 0.4 \mathrm{a}$ \\
\hline Gray & $2.637 \pm 0.30 \mathrm{~b}$ & $12.6 \pm 1.33 \mathrm{~b}$ & $38.70 \pm 7.4 \mathrm{a}$ & $51.70 \pm 7.4 \mathrm{a}$ & $2.15 \pm 0.29 \mathrm{~b}$ & $0.74 \pm 0.04 \mathrm{a}$ \\
\hline Piebald & $3.225 \pm 0.42 \mathrm{a}^{* * *}$ & $15.35 \pm 0.81 \mathrm{a}$ & $36.82 \pm 2.66 \mathrm{a}$ & $49.82 \pm 2.66 \mathrm{a}$ & $2.41 \pm 0.11 \mathrm{a}^{*}$ & $0.73 \pm 0.01 \mathrm{a}$ \\
\hline $\begin{array}{c}\text { Overall } \\
\text { means }\end{array}$ & 3.006 & 14.640 & 36.896 & 49.896 & 2.233 & 0.736 \\
\hline
\end{tabular}

Table 3 : Mean \pm SD for Effect of geese sex on weight and blood traits.

\begin{tabular}{|c|c|c|c|c|c|c|}
\hline Sex & Live weight (kg) & Hemoglobin g/ $100 \mathrm{~cm}^{3}$ & Hetrophil \% & Lymphocyte \% & Monocyte \% & H/L ratio \\
\hline Male & $3.072 \pm 0.31 \mathrm{a}^{*}$ & $15.06 \pm 2.26 \mathrm{a}$ & $37.56 \pm 8.01 \mathrm{a}$ & $50.23 \pm 8.01 \mathrm{a}$ & $2.14 \pm 0.40 \mathrm{~b}$ & $0.735 \pm 0.04 \mathrm{a}$ \\
\hline Female & $2.941 \pm 0.54 b$ & $14.21 \pm 2.52 \mathrm{a}$ & $36.56 \pm 4.44 \mathrm{a}$ & $49.56 \pm 4.44 \mathrm{a}$ & $2.33 \pm 0.24 \mathrm{a}^{*}$ & $0.735 \pm 0.02 \mathrm{a}$ \\
\hline
\end{tabular}

Table 4: Mean \pm SD for Interaction between sex and breed on all traits under study.

\begin{tabular}{|c|c|c|c|c|c|c|c|}
\hline Strain & Sex & Live weight (kg) & $\begin{array}{c}\text { Hemoglobin g/ } \\
100 \mathrm{~cm}^{3}\end{array}$ & Hetrophil \% & Lymphocyte \% & Monocyte \% & H/L ratio \\
\hline White & $\begin{array}{c}\text { Male } \\
\text { Female }\end{array}$ & $\begin{array}{c}3.467 \pm 0.05 a \\
2.85 \pm 0.15 b\end{array}$ & $\begin{array}{c}17.65 \pm 1.25 \mathrm{a}^{*} \\
14.3 \pm 3.5 \mathrm{bc}\end{array}$ & $\begin{array}{c}52.25 \pm 10.5 \mathrm{a} \\
44.10 \pm 1.6 \mathrm{a}\end{array}$ & $\begin{array}{c}1.7 \pm 0.01 \mathrm{~d} \\
2.58 \pm 0.03 \mathrm{a}^{* *}\end{array}$ & $\begin{array}{c}34.25 \pm 10.55 \mathrm{a} \\
31.1 \pm 1.6 \mathrm{a}\end{array}$ & $\begin{array}{c}0.74 \pm 0.05 a \\
0.70 \pm 0.01 a\end{array}$ \\
\hline Gray & $\begin{array}{c}\text { Male } \\
\text { Female }\end{array}$ & $\begin{array}{c}2.90 \pm 0.16 b \\
2.375 \pm 0.12 c\end{array}$ & $\begin{array}{c}12.75 \pm 0.75 \mathrm{c} \\
12.45 \pm 1.95 \mathrm{bc}\end{array}$ & $\begin{array}{c}50.70 \pm 11.4 \mathrm{a} \\
52.7 \pm 2.0 \mathrm{a}\end{array}$ & $\begin{array}{c}2.105 \pm 0.24 b c \\
2.195 \pm 0.39 c\end{array}$ & $\begin{array}{c}37.7 \pm 11.4 \mathrm{a} \\
39.7 \pm 2.0 \mathrm{a}\end{array}$ & $\begin{array}{c}0.73 \pm 0.06 \mathrm{a} \\
0.75 \pm 0.009 \mathrm{a}\end{array}$ \\
\hline Piebald & $\begin{array}{c}\text { Male } \\
\text { Female }\end{array}$ & $\begin{array}{c}3.60 \pm 0.10 \mathrm{a}^{* *} \\
2.85 \pm 0.15 \mathrm{~b}\end{array}$ & $\begin{array}{c}15.9 \pm 0.7 \mathrm{ab} \\
14.8 \pm 0.5 \mathrm{abc}\end{array}$ & $\begin{array}{c}47.75 \pm 0.15 \mathrm{a} \\
51.9 \pm 2.2 \mathrm{a}\end{array}$ & $\begin{array}{l}2.52 \pm 0.01 \mathrm{ab} \\
2.31 \pm 0.01 \mathrm{abc}\end{array}$ & $\begin{array}{c}34.75 \pm 0.15 a \\
38.9 \pm 2.20 a\end{array}$ & $\begin{array}{c}0.72 \pm 0.001 \mathrm{a} \\
0.74 .9 \pm 0.01 \mathrm{a}\end{array}$ \\
\hline
\end{tabular}

Table 5: Band numbers and bands size range (bp) in native geese

\begin{tabular}{|c|c|c|c|c|c|c|c|c|c|c|c|c|c|c|}
\hline \multicolumn{15}{|c|}{ Breeds } \\
\hline \multirow{3}{*}{$\begin{array}{c}\text { Primer } \\
\text { name }\end{array}$} & \multicolumn{4}{|c|}{ White } & \multicolumn{4}{|c|}{ Piebald } & \multicolumn{4}{|c|}{ Gray } & \multicolumn{2}{|c|}{ Over All } \\
\hline & \multicolumn{2}{|c|}{ Male } & \multicolumn{2}{|c|}{ Female } & \multicolumn{2}{|c|}{ Male } & \multicolumn{2}{|c|}{ Female } & \multicolumn{2}{|c|}{ Male } & \multirow{2}{*}{$\begin{array}{c}\text { Female } \\
\text { No. of } \\
\text { band }\end{array}$} & \multicolumn{2}{|c|}{ Bands } & \multirow{2}{*}{$\begin{array}{c}\begin{array}{c}\text { Size } \\
\text { range, bp }\end{array} \\
\begin{array}{c}\text { Size } \\
\text { range, bp }\end{array}\end{array}$} \\
\hline & $\begin{array}{l}\text { No. of } \\
\text { band }\end{array}$ & $\begin{array}{c}\text { Size } \\
\text { range, bp }\end{array}$ & $\begin{array}{c}\text { No. of } \\
\text { band }\end{array}$ & $\begin{array}{c}\text { Size } \\
\text { range, bp }\end{array}$ & $\begin{array}{l}\text { No. of } \\
\text { band }\end{array}$ & $\begin{array}{c}\text { Size } \\
\text { range, bp }\end{array}$ & $\begin{array}{c}\text { No. of } \\
\text { band }\end{array}$ & $\begin{array}{c}\text { Size } \\
\text { range, bp }\end{array}$ & $\begin{array}{c}\text { No. of } \\
\text { band }\end{array}$ & $\begin{array}{c}\text { Size } \\
\text { range, bp }\end{array}$ & & $\begin{array}{c}\text { Size } \\
\text { range, bp }\end{array}$ & $\begin{array}{l}\text { No. of } \\
\text { band }\end{array}$ & \\
\hline OPA-04 & 13 & $100-880$ & 13 & $100-880$ & 16 & $100-880$ & 16 & $100-880$ & 16 & $100-950$ & 16 & $100-950$ & 90 & $100-950$ \\
\hline OPA-14 & 10 & $100-650$ & 10 & $100-650$ & 8 & $100-650$ & 10 & $100-650$ & 4 & $300-1000$ & 4 & $100-850$ & 46 & $100-850$ \\
\hline OPA-20 & 13 & $110-1250$ & 12 & $110-1250$ & 6 & $200-1100$ & 6 & 200-1100 & 9 & $100-1100$ & 8 & $100-1100$ & 54 & $100-1250$ \\
\hline OPB-01 & 6 & $250-1400$ & 6 & $320-1500$ & 8 & $130-1700$ & 9 & $130-1700$ & 7 & $150-2000$ & 7 & $150-2000$ & 43 & $150-2000$ \\
\hline OPB-07 & 8 & $150-1500$ & 8 & $150-1500$ & 4 & $450-1250$ & 4 & $450-1250$ & 3 & $300-1250$ & 3 & $300-1250$ & 30 & $150-1500$ \\
\hline OPB-12 & 7 & $110-900$ & 7 & $110-900$ & 8 & $120-900$ & 8 & $120-900$ & 8 & $130-9000$ & 8 & $130-900$ & 46 & $110-900$ \\
\hline Total & 57 & $100-1500$ & 56 & $100-1500$ & 50 & $100-1700$ & 53 & $100-1700$ & 47 & $100-2000$ & 46 & $100-2000$ & 309 & $100-2000$ \\
\hline
\end{tabular}




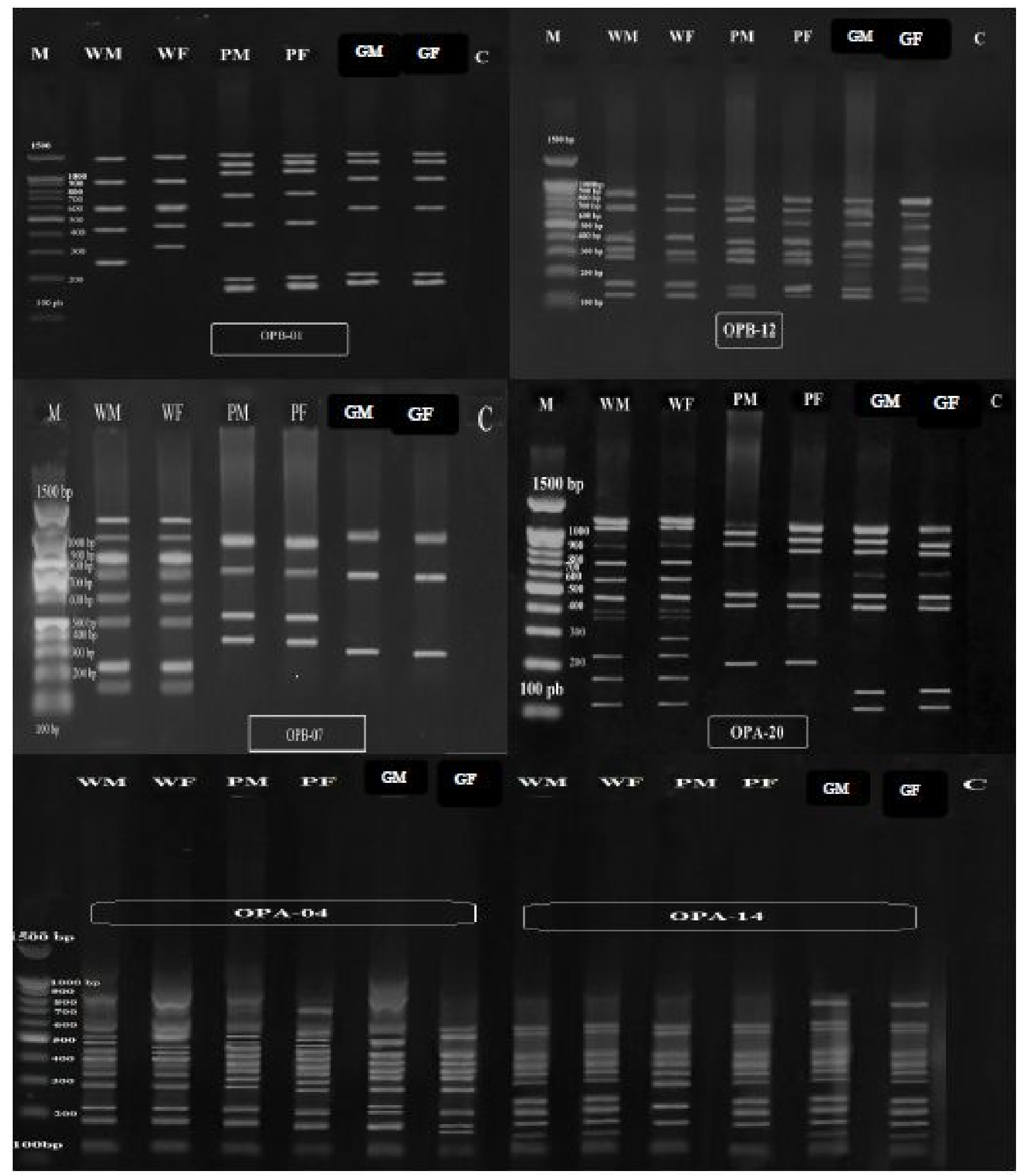

Figure 2: Gel electrophoresis for six RAPD- Primers in geese breeds.

Where: WM White male; WF White female; PM Piebald Male; PF Piebald female; GM Gray male; GF Gray female. 